Krystyna Kowalik •

Instytut Języka Polskiego Polskiej Akademii Nauk, Kraków

krystynakowalik@gmail.com

\title{
JĘZYK I JĘZYKOZNAWSTWO WEDŁUG KRYSTYNY PISARKOWEJ (1932-2010)
}

Słowa klucze: Krystyna Pisarkowa, język, językoznawstwo

Keywords: Krystyna Pisarkowa, language, linguistics

Nagłówek tego artykułu jest kontaminacją tytułów, którymi opatrzyła przynajmniej trzy swoje publikacje prof. Krystyna Pisarkowa, autorka tekstów będących przedmiotem analizy pod kątem informacji na temat pojmowania przez Nią terminów język i językoznawstwo: Język według Junga (1994a), Język według Bronisława Malinowskiego (1995a) i Jęzkkoznawstwo Bronisława Malinowskiego (200ob, 200oc), prac, które zgodnie z dokonaną przez Walerego Pisarka (2010) periodyzacją życiorysu Pisarkowej przypadły na przełom Jej młodości i naukowej dojrzałości.

Po raz drugi przychodzi mi się zmierzyć z nazwiskiem Pisarkowej, z Jej dorobkiem, osobowością i legendą (por. Kowalik 2010). I jest to tym trudniejsze, że dziś trzeba także uwzględnić liczne teksty powstałe z inspiracji Jej pracami i wspomnienia, które się pojawiły, gdy - jak napisał prof. Pisarek - „Odeszła nagle, bez pożegnania" (Pisarek 2010: 20).

Moje doświadczenia w kontaktach z docent, a później profesor Pisarkową są skromne, choć od samego początku poważne, bo pół wieku temu zakwalifikowała do druku w "Języku Polskim” dwa moje teksty, w tym recenzję książki autorstwa W. Pisarka Frekwencja wyrazów w prasie (Kowalikówna 1974). To wtedy zauważyła, że mamy to samo imię i ten sam znak zodiaku. Być może był to szczegół, który sprawił, że wszystkie ścieżki wiodły mnie ku Niej. Po latach dowiedziałam się, że „od dziecka pociągała Ją magia, horoskopy, wróżby z kart, z ręki itp.” (Pisarek 2010: 15). Łączył nas także krakowski adres Straszewskiego 27, gdzie swoją siedzibę miał Zakład 
Językoznawstwa PAN, późniejszy Instytut Języka Polskiego PAN, bo nasza Pracownia Budowy Gramatycznej Współczesnego Języka Polskiego sąsiadowała z Pracownią Składni Historycznej, którą Pisarkowa kierowała po tragicznej śmierci (1969) prof. Zenona Klemensiewicza. Zbliżyły nas również wyjazdy do Warszawy, by w Pałacu Staszica uczestniczyć w szkoleniach z zakresu nowszych metod stosowanych we współczesnej lingwistyce, i różne konferencje okołogramatyczne (a przy okazji i pokoje hotelowe). A potem zostałam Jej koleżanką ${ }^{1}$ redakcyjną, kiedy w 1988 r. dołączyłam do zespołu Redakcji „Języka Polskiego”. Jako jedna z najmłodszych w tym zespole Pisarkowa była bardzo zaangażowana w prace redakcyjne (może warto przypomnieć, że był to czas, gdy Redakcji przewodniczył prof. Stanisław Urbańczyk, członkami zaś byli: prof. prof. Maria Dłuska, Antonina Obrębska-Jabłońska, Jan Safarewicz, Władysław Kuraszkiewicz, Karol Dejna, Franciszek Sławski, Marian Kucała, doc. Józef Reczek). Gdy w roku 2004 Pisarkowa objęła funkcję redaktora naczelnego „Języka Polskiego”, stała się także moją szefową.

Kim była, kim nadal jest, że mimo upływu lat Jej postać wciąż angażuje uwagę? Pamiętamy szczegóły życiorysu (czyją była córką, żoną, matką, babką) i inne fakty, daty, tytuły Jej artykułów. Odpowiedzi, nawet expressis verbis, są w Jej własnych tekstach.

Na wizerunek uczonej intensywnie pracowała od chwili, gdy w 1949 r. - wtedy jeszcze jako Krystyna Harrerówna - przyjechała z Gdańska do Krakowa, by podjąć studia na Uniwersytecie Jagiellońskim, gdy dla polonistyki zrezygnowała z muzykologii. Umiała dostrzec szansę, którą stwarzało ówczesne krakowskie środowisko uniwersyteckie (z filozofem Romanem Ingardenem, literaturoznawcami: Juliuszem Kleinerem, Stanisławem Pigoniem, i językoznawcami: Kazimierzem Nitschem, Zenonem Klemensiewiczem, Tadeuszem Lehrem-Spławińskim, Jerzym Kuryłowiczem, Witoldem Taszyckim, Marią Dłuską, Tadeuszem Milewskim i kilku dalszymi). Jakkolwiek wielokrotnie pisała o wielkiej roli swoich nauczycieli w kształtowaniu Jej naukowej tożsamości, to jednak poszła swoją drogą, co więcej - „poszła pod prąd” (Urbańczyk 1994: 5), wybierając składnię, która stała się Jej tematem życia. Była „samodzielna” (ibid.: 6) i jak wspomina Jej koleżanka z Pracowni Składni Historycznej Anna Kałkowska, „Krystyna wcześnie rozpoczęła twórczość naukową "na własne konto", praca zespołowa nie była bowiem jej żywiołem” (Kałkowska 2010b: 18), a w opinii wspomnianego S. Urbańczyka Pisarkowa „od napisania rozprawy doktorskiej hulała po językoznawstwie coraz swobodniej" (Urbańczyk 1994: 6), poszerzając obszar naukowej eksploracji o dyscypliny u nas mniej popularne lub wręcz nieobecne. „Rok po roku przynosił nowe artykuły, zawsze pomysłowe, lecz wszystko to przyćmiła książka pt. »Składnia rozmowy telefonicznej«" (ibid.). Każda następna publikacja była wydarzeniem,

1 W ten sposób uhonorowała mnie w aliterowanej dedykacji na egzemplarzu świeżo wydanej Pragmatyki przekładu (Pisarkowa 1998). 
a książka o wyliczankach polskich - po prostu „wystrzałową publikacją” (ibid.: 7). Nie mniejszy entuzjazm wzbudzały artykuły. Na wyselekcjonowanej przez W. Pisarka liście szczególnie ważnych pozycji, zwłaszcza przez biegunowo zróżnicowaną tematykę, znalazły się: „O Ajnach (1972), o modalności (1973), posesywności (1974), neutralizacji opozycji temporalnej (1973), o dosłowności w języku literackim [genialne!] (1977), o przejęzyczeniach [rewelacyjne!] (1977), kreatywności językowej (1978), o tytułowaniu (1979), kauzatywności (1981), o teorii zmiany językowej (1984), o filozofii języka i wolności (1986), a także o nazwach młodzieżowych zespołów muzycznych (1970) i o Przekrojowej rubryce z powiedzonkami »Heca hecą" (1971)" (Pisarek 2010: 14), dwa artykuły - jak widać - opatrzone zostały dodatkowymi, wysoko je waloryzującymi komentarzami.

K. Pisarkowa szybko stała się znana z niezwykle szerokich zainteresowań naukowych - od historii języka, zwłaszcza składni polskiej na różnych etapach jej rozwoju, przez zagadnienia filozofii języka i jego artystycznej postaci w zróżnicowanych formach literackiej ekspresji, interpretację tekstów o różnej proweniencji, semantykę, pragmatykę, po teorię przekładu międzyjęzykowego i intersemiotycznego, folklor i język w wariancie mówionym. Dostrzegała wartości, o jakie wzbogacały wiedzę o języku nowe metodologie, ale umiała też dostrzec ich uproszczenia, które miały służyć wyrazistości koncepcji, a może też bezradność wobec pragmatyki codziennych zachowań językowych. Nie pomijała doniosłości pojęcia systemu, ale podkreślała ważność wyjątków, ich urodę, konieczność uwzględniania kontekstu i potrzebę powrotu do filologicznej analizy tekstu. Rozległość problematyki to nie tylko pochodna kontaktów z licznymi pozapolskimi środowiskami lingwistycznymi, ale i otwartość na innowacyjne koncepcje, wyjątkowa wyobraźnia i umiejętność oglądu zjawisk z różnych perspektyw, dar wychwytywania subtelności i znajdowania dla nich właściwych środków wyrazu. Coraz to nowsze, zaskakujące swoją odkrywczością wątki dopiero z czasem znajdowały naśladowców. K. Pisarkowa cieszyła się opinią niekwestionowanego autorytetu w wielu dziedzinach, wiele osób, mimo dystansu i respektu, jaki wzbudzała, zabiegało o kontakt z Nią, także dla Jej walorów osobowych.

I choć ciągle żywo pamiętam uwagę Romana Laskowskiego, że „Postęp w nauce polega $\mathrm{w}$ znacznym stopniu na porządkowaniu zastanego systemu pojęć poprzez wykrycie założeń, na jakich ten system pojęć jest zbudowany" (Laskowski 1987: 120), to jednak ustalenie, jak K. Pisarkowa rozumiała przywołane w tytule pojęcia języka i językoznawstwa, nie przychodzi łatwo. W liczącej ponad 350 tekstów Jej bibliografii i wśród niewymienianych w tych zestawieniach z nazwy blisko stu haseł Jej autorstwa w Encyklopedii wiedzy o języku polskim (Urbańczyk 1978, por. też Urbańczyk 1991) trudno wskazać pozycję, której tytuł obiecywałby gotowe definicje interesujących nas pojęć. Zresztą kiedyś napisała, że nie rozwija pewnych wątków z szacunku dla odbiorcy, żeby go nie urazić, bo uważała je za zbyt oczywiste. Jeśli więc chcemy poznać interpretację pojęć i terminów w ich historycznym i pragmatycznym 
uwikłaniu, musimy sami do nich dotrzeć zalecaną przez Nią filologiczną metodą czytania, tym razem Pisarkowej, i wyłuskiwania z tekstów sformułowań, z których jak z rozrzuconych chronologicznie puzzli - można próbować szkicować teorię języka i językoznawstwa, jednak bez pewności, że jest zgodna z Jej duchem.

W dorobku Pisarkowej jest kilkanaście publikacji, których tytuły zawierają terminy język i językoznawstwo. Pojawiały się one co jakiś czas w coraz to nowszych konfiguracjach tematycznych. We wszystkich jednak zostały uwikłane w kontekst sprawiający wrażenie, że nie one są w nim najważniejsze.

K. Pisarkowa miała już w dorobku dziesięć publikacji, gdy zamieściła $\mathrm{w}$ „Języku Polskim" artykuł Pomocnicze elementy języka muzykologii (1963/1994). Sześć lat później pisała o Głównych zasługach profesora Klemensiewicza dla kultury języka (1969a) i... tresurze poprzez język (1969b). Jako 37 pozycję do swojej bibliografii dodała Tango po niemiecku. Na marginesie niektórych przekładów z Mrożka na język niemiecki (1967a), gdzie wykorzystała wyniesione z domu kompetencje w zakresie dwóch języków. Poza jednostkowym użyciem języka niemieckiego w Jej tekstach pisanych po polsku pojawia się tylko język polski: Konotacja semantyczna nazw narodowości w języku polskim (1976a). Dalsze tytuły sygnalizują zainteresowanie zróżnicowaniem polszczyzny, a dokładniej jej odmianami. Interesował Ją język naturalny (Rozważania o argumentacji w języku naturalnym, 1977c), literacki (O dosłowności w języku literackim, 1977b), język potoczny (Odchylenie a kreatywność w języku potocznym, 1977a, Odchylenie twórcze w języku potocznym, 1978b). Potem przywołała pojęcie wspólnego języka (Językoznawstwo Bronisława Malinowskiego, t. 1: Więzy wspólnego języka, 200ob) i języków pierwotnych (Językoznawstwo Bronisława Malinowskiego, t. 2, 2000c). W zastępstwie języka pojawiała się czasem mowa (Mowa a postaci dewerbalizacji, 2001, Zaimek w polskim zdaniu. 1. Obserwacje podmiotu zaimkowego $w$ mowie potocznej, 1967b, Pragmatyczne spojrzenie na akt mowy, 1976b), a gdy tekst dotyczył języka polskiego, używała leksemu polszczyzna (Szkic pola semantycznego zapachów w polszczyźnie, 1972, Możliwości i ograniczenia opisu zmian składniowych w polszczyźnie, 1981). Tytuły sygnalizują również zagadnienia z różnych poziomów języka, zwłaszcza syntaktycznego (Historia składni języka polskiego, 1984). Z zagadnień mieszczących się w polu języka w Jej pracach pojawiła się filozofia języka (W kręgu filozofii języka i wolności, 1986b), kultura języka (Główne zasługi profesora Klemensiewicza dla kultury języka, 1969a), historia języka (Z pragmatycznej stylistyki, semantyki i historii języka, 1994b, Historia języka a historia sztuki, 200oa). Do tematów ogólniejszych należy dyscyplina, której przedmiotem jest język - językoznawstwo obok rzadszej lingwistyki (Miejsce składni historycznej we współczesnym językoznawstwie polskim, 1973, Roman Ingarden a językoznawstwo, 1971 i Adam Heinz jako historyk językoznawstwa, 1986a).

Dokładne zreferowanie nawet tak zawężonego tematu znacznie przekracza możliwości artykułu, więc ograniczam się do kilku, ale znaczących pozycji. Mam świadomość arbitralności swoich decyzji co do doboru tekstów i ich merytorycznego 
uporządkowania. Wydaje mi się jednak, że przywołane poniżej obserwacje i myśli Pisarkowej zasługują na uwagę, refleksję, może nawet na zapamiętanie.

„Człowiek klasyfikuje prawdopodobnie wszystko - pisze prof. Pisarkowa - bo wybór i porządkowanie jest koniecznym warunkiem naszego przeżycia. Zapewne jednym z pierwotnych i ogólnych kryteriów klasyfikacji jest podział na dobre i złe, czyli kwalifikacja oceniająca” (Pisarkowa 1999: 109). „Nauka zawsze dąży do ujawnienia prawdy. Ale to wspólne dążenie zawsze wymaga od nauki haraczu, którym jest milcząca zgoda na fałsz uogólnienia” (ibid.: 111). Rozwijając ten wątek, stwierdzała za Karlem Popperem, że „Dwie z najistotniejszych dla ewolucji wiedzy wynalezionych wartości to "postawa krytyczna oraz prawda obiektywna«" (Popper 1996: 61-62). To one - zdaniem Pisarkowej - powinny być motywem do poszukiwania teorii. Poszukiwanie korespondencji prawdy z faktami, czyli funkcjonowanie owych wartości, umożliwia ,język, najważniejszy produkt ludzkiego umysłu”, który równocześnie pozwala na ogląd teorii, „,jak gdyby należały do świata poza nami” (ibid.). Doniosłość Popperowskiej obserwacji rekapitulowała Pisarkowa uwagą, iż chodzi tu o to, „,o językoznawstwo postrzega jako funkcję metajęzykową, jedną z najistotniejszych funkcji języka" (Pisarkowa 1999: 115).

Pojmując język „jako najdobitniejszy znak człowieczeństwa, a język narodu jako najuchwytniejszą cechę narodu" (Pisarkowa 1969a: 249), badaczka uznała, że czynnikiem, który wyznacza kierunek nauki o języku, jest kultura języka, zarówno $\mathrm{w}$ aspekcie teoretycznym, jak i praktycznym. Wykorzystując w tej dziedzinie materiały i działalność prof. Z. Klemensiewicza, wydobywała istotne dla zagadnienia ustalenia dotyczące dziejów miłośnictwa języka, podtrzymywała Klemensiewiczowską potrzebę popularyzacji językoznawstwa i upowszechniania kultury języka, podkreślała osiągnięcia w zakresie teorii kultury języka, to jest dokumentacji materiału, ustaleń terminologicznych (między innymi pojęcie i granice normy), tendencji zmian językowych, udziału jednostki w kształtowaniu języka, stylistycznego zróżnicowania języka.

Nawiązując do wspomnianej wyżej roli jednostki w procesie kształtowania języka, warto zwrócić uwagę na teksty Pisarkowej poświęcone uczonym, którzy nie tylko byli autorytetami w zakresie normy językowej, ale i odegrali ważną rolę w kształtowaniu teorii lingwistycznej. Spośród sporej grupy uczonych, którym Pisarkowa poświęciła swoje teksty, trzeba wymienić filozofa R. Ingardena i językoznawców, poza wspomnianym Z. Klemensiewiczem także Adama Heinza, J. Kuryłowicza i T. Milewskiego.

O Klemensiewiczu pisała co najmniej ośmiokrotnie (por. np. Pisarkowa 1969a, 1969c), nie tylko jako o swoim fascynującym profesorze, wykładowcy, promotorze pracy magisterskiej i doktorskiej, przełożonym, ale i o jego dorobku polonistycznym, skrupulatnie wyliczając pola działania i szczególne zasługi w dziedzinie kultury języka, o jego autorytecie naukowym. Jego idee badań składniowych kontynuowała i rozwijała w swoich publikacjach i zadedykowała mu swoje najważniejsze 
dzieło - Historię składni języka polskiego (1984). Wspominała jego naukową pasję, zaangażowanie w dydaktykę na różnych szczeblach i na różnych forach kształcenia, ale i talenty, którymi obdarzyła go natura, punktualność, elegancję i takt w relacjach międzyludzkich.

Sylwetkę T. Milewskiego (1906-1966) przypomniała na łamach „Języka Polskiego" (Pisarkowa 2006) w czterdziestolecie jego śmierci. Długa jest lista powodów, dla których spotkania z profesorem zapadały w pamięć, bo podejmował tematy daleko wykraczające poza dyscyplinę polonistyczną (teorię języka, historię językoznawstwa, typologię i geografię lingwistyczną, zagadnienia dotyczące języków indoeuropejskich i nieindoeuropejskich, kultury Indian amerykańskich), a z problematyki polonistycznej również budzące emocje próby ustalenia proweniencji polskiego języka literackiego. Skupiał wokół siebie ludzi ciekawych świata, podsuwał lektury, o które nie było łatwo w polskiej rzeczywistości, co nieraz owocowało publikacjami. Nietrudno dostrzec w dorobku Pisarkowej pozycje, w których widać ślady inspiracji tamtymi spotkaniami. Nieobojętne też były zapewne walory osoby profesora, empatycznego, zainteresowanego sprawami swoich podopiecznych, studentów i doktorantów.

Swoją fascynacją naukową sylwetką prof. J. Kuryłowicza (1895-1978) Pisarkowa podzieliła się z czytelnikami „Przekroju” (1978a). Jej podziw budziła nie tylko swoboda, z jaką poruszał się po materiale języków żywych i dawno wymarłych, bliższych i odległych typologicznie, ale i dociekliwość badawcza, niezwykła intuicja, umiejętność stawiania pytań i formułowania uogólnień o faktach, odkrywania praw, według których funkcjonują elementy w systemach języków naturalnych, przewidywania zmian i budowania teorii.

Nazwisko A. Heinza (1914-1984) pojawiło się w związku z jego publikacją Dzieje językoznawstwa w zarysie (Heinz 1978), co dało Pisarkowej asumpt do sportretowania go jako historyka językoznawstwa (Pisarkowa 1986a). Za pierwszoplanowy walor książki uznała to, że jest „zbudowana na wyrazistej filozofii historii lingwistyki” (ibid.: 13), że autor napisał ją z autopsji, opierając się na własnej lekturze tekstów, że zrezygnował z kompilacji i referowania innych, wcześniejszych podsumowań. Zdaniem Pisarkowej Heinz - mimo uznania dla gramatyków hinduskich - wyraźnie faworyzował Greków i to im przypisywał „pierwsze naprawdę naukowe widzenie języka. [...] Im to zawdzięczamy odkrycie dwuklasowości struktury języka [...], ich przeczuciom - odróżnienie systemu i tekstu, ujrzenie izomorfizmu faktów i zjawisk językowych" (ibid.: 14). Heinz, pisząc o powstaniu językoznawstwa diachronicznego, wykorzystał porównanie czystej synchronii do malarstwa bez perspektywy, co Pisarkowa - badaczka uprawiająca językoznawstwo o silnych korzeniach historycznych - uznała za wyjątkowo trafne obrazowanie. W Jej oczach Heinz jawił się „jako filozof głęboko wierzący w założony, idealny porządek świata i opisywanego obiektu” (ibid.). Metodologicznie najbliższy był mu strukturalizm, jednak wobec zaistniałych faktów stwierdził: „Każda epoka dochodzi do okresu swej kulminacji, po 
którym następuje albo jej upadek, albo przewartościowanie [...]” (cyt. za: ibid.: 15), tym, co się okazało trwałe w ewolucji lingwistyki, była semantyka (ibid.: 14).

R. Ingarden (1893-1970) - zdaniem Pisarkowej - uprawiający filozofię w sposób wszechstronny, był żywo zainteresowany problemami i metodami językoznawczymi, „zabierał głos w sprawach najistotniejszych dla językoznawstwa” (Pisarkowa 1971: 3). Szeroko znane jest jego stanowisko w kwestii roli języka w dziele literackim, zwłaszcza w poezji, i rozważania dotyczące składników znaczenia słowa oraz postulat jego analizy na tle kontekstu syntaktycznego. $Z$ analizy jednego typu wyrazu wnioskował o dyspozycjach pozostałych wyrazów, co pozwoliło mu na wyodrębnienie między innymi gramatycznych części mowy. Wyrazy uważał za składniki języka o ustalonym brzmieniu i znaczeniu, które umożliwiają ich użycie w zdaniach. Poza semantyką wyrazu interesował się semantyką grupy i zdania, zwłaszcza gdy pojawiły się koncepcje transformacyjno-generatywne. Krytycznie oceniał między innymi fonologiczne koncepcje szkoły praskiej, podobnie odnosił się do językoznawstwa statystycznego. Ingarden inspirował nie tylko, gdy rozwijał pewne koncepcje, ale też wtedy, gdy z niektórymi polemizował. Za godny upowszechnienia uznała Pisarkowa ustalony przez Ingardena „system określeń językowych dla systemu wartości estetycznie doniosłych" (ibid.: 8-9).

„Język naturalny ma swoją historię, znaczenia wyrazów - swoje ewolucje” (Pisarkowa 1999: 113). „[...] wraz ze zmianą języka i wraz z rozwojem nauki zmieniają się niepostrzeżenie także języki nauk. [...] wymaga podejścia historycznego sam język. Jego sprzeczna natura: zmienna, podatna na wpływ czasu, a jednocześnie przez zbiorową tradycję stale kontrolowana, wymaga jednocześnie diachronicznego i synchronicznego spojrzenia" (ibid.: 117). O dychotomiczne podejście upomniała się Pisarkowa także w odniesieniu do językoznawstwa, o wyróżnienie dwóch nauk językoznawczych: językoznawstwa historycznego i niehistorycznego (ibid.: 109). Twierdziła bowiem, że „Istota nauki, odkrywanie $i$ wielomodelowe wyjaśnianie prawdy, to wprowadzanie zmian w panujących stanach świadomości i legalizowanie zmian uświadomionych" (ibid.: 115, zob. też Pisarkowa 2007).

Język jest produktem historii, co więcej, K. Pisarkowa mówiła nawet o władzy historii nad językiem, którego wszystkie zmiany występują w porządku chronologicznym, co daje możliwość ustalenia chronologii względnej zmiany wobec innej. Różnic między wyrazami pozornie równoznacznymi upatrywała w odmienności właśnie ich historii (Pisarkowa 1992).

Jako ilustracja uwarunkowania takich zmian może służyć ewolucja koncepcji języka B. Malinowskiego, przywołana w kontekście analizy pojęcia wolności (Na marginesie wolności. Z pytań Malinowskiego do językoznawstwa, Pisarkowa 1996: 231):

Zadaniem języka miało niegdyś być służenie najprostszym funkcjom pragmatycznym. [...] Takim go widział, obserwując pracę, praktyki magiczne, dramaty i rozrywki Trobriandczyków. Później [...] z dystansu lat i przestrzeni dzielącej go od Trobriandów nie tylko przyzna językowi oprócz funkcji pragmatycznej - symboliczną. 
Teraz wyprowadza jedną z drugiej, umieszczając symboliczną funkcję w hierarchii kulturowej wyżej, skoro twierdzi, że to z gestów rozwinęły się symbole.

„Język i odpowiednie symbole szkicują sensy wszelkich wartości kolektywnych i indywidualnych [...]" (ibid.: 234; zob. też Pisarkowa 2002). Co więcej, K. Pisarkowa uważała, że język kieruje myśleniem, nadaje kształt naszej świadomości i uczuciom. Bez języka człowiek staje się bezradny, wręcz bezdomny, a rezygnacja z języka ojczystego może skutkować zmianą osobowości (Pisarkowa 1992).

Ewolucyjny charakter ma również wywodzone $\mathrm{z}$ renesansu, pozytywnie nacechowane pojęcie kreatywności „jako określenie ludzkich możliwości [...] w [...] metaforycznym użyciu” (Pisarkowa 1978c: 14) ${ }^{2}$, zastosowane najpierw w psychologii (XIX w.) bez wartościowania, a zajmujące „dziś pozycję centralną w teorii językoznawstwa" (ibid.: 13). Pojęcie kojarzone z nazwiskiem Wilhelma von Humboldta ewoluuje od koncepcji obejmującej „i wytwór, i siły wytwórcze” w kierunku pojęcia włączającego „kategorie czysto pojęciowe: mity, podania, wierzenia ludowe” (ibid.: 15). W rozumieniu Noama Chomsky’ego kreatywność językowa to „umiejętność tworzenia i rozumienia nieskończonej ilości zdań”, a także przypisywana rodowitym użytkownikom języka (native speakers) umiejętność rozpoznawania zdań niepoprawnych (ibid.: 14). W opinii Pisarkowej „Kreatywność Humboldtowska, poetycko idealistyczna i Chomsky’ego kreatywność (generatywność) dwudziestowieczna nie są tym samym [...]. Wspólne jest im to, że są procesami, a nie cechami procesów. [...] Dla Chomsky'ego generatywna jest gramatyka - nie język" (ibid.: 17-18). W koncepcji strukturalistycznej - jak konstatowała Pisarkowa - nie ma miejsca dla pojęcia kreatywności (ibid.: 21). Ważnym momentem dla interpretacji znaczenia kreatywności było wprowadzenie przez Romana Jakobsona dwóch dalszych pojęć: metafory i metonimii, umożliwiających interpretowanie „wszelkich znaków językowych w dwóch wymiarach” - wertykalnym przez podobieństwo do innych znaków oraz horyzontalnym na podstawie kombinacji i przyległości (ibid.: 28). „Język w ogóle polega na interpretowaniu rzeczywistości przy pomocy metafor” (ibid.: 29).

Język jako narzędzie działania mające wpływ na zachowanie człowieka może się okazać środkiem przymusu (Pisarkowa 1996: 234), a o sile zorganizowanej i sprawnej propagandy uczona pisała na marginesie sztuki-widowiska Petera Handke $\mathrm{Ka}$ spar, rozwijając tytuł - czyli tresura poprzez język (Pisarkowa 1969b).

Inny aspekt rozważań dotyczących języka dokumentuje niewielka książeczka wydana w PAN-owskiej serii „Nauka dla Wszystkich” Język według Junga. O czytaniu intencji (1994a). O wyborze na lekturę tekstów Junga zadecydowała nie tylko ich treść, ale - być może - i osobowość ich autora. Carl Gustav Jung (1875-1961) z wykształcenia był lekarzem, z zamiłowania podróżnikiem, był profesorem w Zurychu

2 Przytoczone refleksje K. Pisarkowej dotyczące pojęcia kreatywności to efekt Jej wnikliwej lektury publikacji Bernarda Imhasly'ego (1974). 
i Bazylei związanym przez jakiś czas z Sigmundem Freudem, był także filozofem o dorobku liczącym 20 tomów, twórcą własnej szkoły psychologii analitycznej. Dla Pisarkowej, zainteresowanej językoznawstwem pragmatycznym, publikacje Junga stały się doskonałym materiałem do poszukiwania odpowiedzi na pytanie, jak dokonujemy działań za pomocą języka, czego dokonujemy językiem. „A pytamy dlatego, że chcemy się dowiedzieć, jakie są przyczyny i skutki działań językowych” (ibid.: 4). Te przyczyny to intencje aktów mowy, które rzadko są jawne. Stopień jawności intencji nie jest oczywisty, dlatego że w naszym życiu ważną rolę odgrywa podświadomość. Formułowaniu intencji lub ich maskowaniu służy wybór kodu. Budowanie kodu to nadawanie znaczeń użytym znakom, a decyduje o nim podświadomość, której jako uczestniczki komunikacji bronił Jung. Źródeł kodu upatrywał w historii, w literaturze i języku etnicznym. Jako argument za istnieniem podświadomości podawał jej uniwersalność, opartą na wspólnocie motywów mitycznych, symboli, archetypów. Z podświadomości - zdaniem Junga - wywodzą się zdolności twórcze, „W niej powstają szkice pierwszych wersji naszych myśli, zapisów, koncepcji” (tekstu poetyckiego, prozy, artykułu, referatu...). „W świetle jego wywodów to właśnie podświadomość okazuje się obiektywna - bo niezależna od naszej świadomej tresury. [...] zasadą podświadomości jest autonomia" (ibid.: 26). Jung przypisuje podświadomości transcendentną funkcję, która manifestuje się we śnie, filozof przygląda się sposobom istnienia w podświadomości archetypu, zastanawia się nad rodowodem mitu, szuka wykładni snu, uruchamia procedury jego deszyfracji. „Poznanie podświadomości sprawia, że świadomość ma szanse stać się mniej jednostkowa, mniej niepowtarzalna, bardziej kolektywna" (ibid.: 30). Przy tej okazji ujawniają się stereotypy. Spośród rozsianych w tekście obserwacji Pisarkowej trzy szczególnie zapadają w pamięć: „Jung stawia zdumiewająco śmiałym gestem znak równości między geniuszem a wariatem” (ibid.: 28), „Każdy z nas ma w sobie coś ze świętego i coś ze zbrodniarza” (ibid.: 30), „Świat jest książką z obrazkami [...]” (ibid.: 28).

„Niespełnione marzenie czynnego uprawiania muzyki - pisze W. Pisarek - rekompensuje pisaniem o niej jak o języku" (Pisarek 2010: 14). Kojarzenie zjawisk $\mathrm{z}$ tak różnych dyscyplin jak językoznawstwo i muzykologia znajduje uzasadnienie i w pokrewieństwie ich elementów, i w doświadczeniach życiowych K. Pisarkowej. Wszak wywodzi się Ona z domu artystycznego: matka Stanisława z Kamińskich była nauczycielką muzyki i pianistką, a i Pisarkowej gra na fortepianie nie była obca, zaś na początku zawodowej samodzielności była związana z Polskim Wydawnictwem Muzycznym. Język muzykologii traktuje jako specjalistyczną odmianę języka ogólnego stosowaną do opisu dzieła muzycznego i jego elementów. Spośród dwóch możliwych form opisu - ściśle naukowego, wykorzystującego terminologię specjalną, i popularnego, dokonywanego przez niespecjalistów lub dla niespecjalistów charakteryzuje tę drugą, gdzie w funkcji terminów występują środki pomocnicze przejęte z języka ogólnego, służące do charakterystyki barwy dźwięków, rysunku (architektoniki utworu), ruchu (opisu melodii), estetyki literackiej (poetyki, 
stylistyki), składni i gramatyki. W niezwykle subtelnych analizach, zdradzających wysokie kompetencje tak w zakresie językoznawstwa, jak i w dziedzinie muzykologii, przyznaje stosowanym określnikom status neosemantyzmów. Wskazując na istotne właściwości elementów muzycznych, pośrednio charakteryzuje elementy językowe: „Przypisywane muzyce funkcje dzieli od funkcji znaku językowego jeszcze jedna, być może najistotniejsza różnica. Mimo związków z określonymi kulturami, etnicznymi i historycznymi - znaki muzyki są ponadnarodowe" (Pisarkowa 1963/1994: 211). Refleksje językoznawczo-muzykologiczne - zdaniem Pisarka - znajdują „dojrzały wyraz w intersemiotycznych analizach wieloznaczności świata i melodii na Psałterz polski Mikołaja Gomółki” (Pisarek 2010: 14; zob. Pisarkowa 1998: 37-59).

Analizując teksty o muzyce, Pisarkowa zauważyła, że ich język charakteryzuje się obecnością metafor i związków frazeologicznych, i cytując Stanisława Skorupkę, skonstatowała

W języku potocznym im przenośnia bardziej utarta i oklepana, tym lepsza. Właśnie oklepaność i pospolitość decyduje o tym, że staje się ona zwrotem językowym [...]. Jest to twierdzenie, które trzeba odnieść także do języka naukowego, w ogóle do języka bez ambicji artystyczno-ekspresywnych, do języka realizującego przede wszystkim funkcję komunikatywną [...] (Pisarkowa 1963/1994: 177).

Od tekstu artystycznego oczekiwała, a może nawet wymagała, przełamywania stereotypów.

$\mathrm{Z}$ innej perspektywy patrzyła Pisarkowa na te dwie formy ekspresji, snując refleksje (Pisarkowa 1988) na marginesie lektury Związków muzyki ze słowem autorstwa Michała Bristigera (1986). W dyskusji - czy nawet w zdecydowanej polemice $\mathrm{z}$ autorem - pokazała krok po kroku, akapit po akapicie, jak wnioski podsumowujące analizy różnych środków przekazu, wbrew pozornym zbieżnościom, wymagają mocnych argumentów i ostrożności w ich uogólnianiu.

Do tematyki muzycznej nawiązała w swojej wypowiedzi dotyczącej stylu, który uważała za predykat wartościujący nie tylko dzieła sztuki, ale i zwykłe przedmioty, a także człowieka (prezydent $w$ wielkim stylu). To wartościowanie generalnie przyjmowała za pozytywne, chyba że - jak twierdziła - odnosi się ono do obiektu deprecjonowanego przez samą nazwę (oszust w wielkim stylu). To właśnie teksty muzyczne wykorzystała jako ilustrację sposobów manifestacji cech relewantnych stylu, kodu, możliwości wartościowania wykonania itd. $\mathrm{W}$ różnorodności zastosowań pojęcia stylu dostrzegała między innymi możliwość identyfikacji odmian języka naturalnego, wyodrębnionych ze względu na cechy charakterystyczne, funkcje, zastosowanie (styl kancelaryjny, naukowy, uroczysty, potoczny...) (Pisarkowa 1995b).

Rozległość tematyki, jakiej poświęcała swoją uwagę Pisarkowa, pozwala uznać językoznawstwo za dyscyplinę humanistyczną o znacznej pojemności, gdzie głównym obiektem jest język we wszystkich jego przejawach i funkcjach, gdzie wszystkie elementy, zarówno te mikro-, jak i makro-, zasługują na uwagę (choć wyraźnie 
widać pewne preferencje uczonej, skoro wśród wielu uwag znalazła się też i taka: „żywym istnieniem, »dziwolągiem« o [...] płynnej istocie jest tzw. system gramatyczny") (Pisarkowa 1999: 117).

Bez wątpienia problemem, któremu Pisarkowa poświęciła najwięcej uwagi, była składnia, zarówno $\mathrm{w}$ aspekcie dokumentacyjnym (por. opracowane zespołowo tomy, poczynając od Zapomniane konstrukcje składni staropolskiej. Wybór przykładów (1966) po Zapomniane konstrukcje składni nowopolskiej (1863-1918). Wybór przykładów (1977) - ZKSS, ZKSŚXVI, ZKSŚXVII, ZKSŚ170o-1780, ZKSN1780-1822, ZKSN1822-1863, ZKSN1863-1918), jak i teoretycznym. Nie zaskakuje więc w Jej bibliografii ani synteza Historia składni języka polskiego (1984), ani próba określenia Miejsca składni historycznej w językoznawstwie polskim (1973).

Zamieszczony prawie przed półwieczem w "Języku Polskim” artykuł nosi wyraźne znamiona owych czasów, kiedy w badaniach dominowała synchronia, a „Zainteresowanie diachronią znalazło się w cieniu i legło odłogiem” (ibid.: 158). Przypominając wcześniejsze badania $\mathrm{w}$ zakresie składni, podważyła Pisarkowa przede wszystkim powszechne wówczas przekonanie, „jakoby się składnia jako odrębny dział językoznawstwa narodziła dopiero w latach trzydziestych XX w." (ibid.: 159160). Wskazała szereg prac $\mathrm{z}$ okresu między- i powojennego, które uznała za istotne osiągnięcie w dorobku w zakresie badania składni. Mając na uwadze przydatność badań diachronicznych dla syntez synchronicznych, sformułowała konkretne cele cząstkowych analiz, które miały wypełnić luki w wiedzy o systemie syntaktycznym, jak zbadanie zjawiska zastępowania składni kazualnej dopełnień wyrażeniami przyimkowymi, kształtowanie się środków wyrazu modalności, spójniki hipotaktyczne i niehipotaktyczne, wyrażanie predykacji oraz strukturalizacja zjawisk stylistycznych - wchodzenie do systemu zjawisk języka mówionego (ibid.: 169-172).

Pisząc o językoznawstwie i języku jako zjawisku społecznym, trudno nie zwrócić uwagi na idiolekt samej Pisarkowej, który jako język osobniczy zdumiewa swoją indywidualnością, niepowtarzalnością. I nie chodzi tu tylko o kreatywność przejawiającą się w dobitności, wariantywności środków wyrazu, zaskakujących asocjacjach, w gromadzeniu szeregów składniowych, swoistej barokowości, ale także w kreowaniu zindywidualizowanego kodu, który przełamuje standardy dyskursu naukowego. Z powodzeniem można do Niej odnieść to, co napisała o Jungu: „omawiane [...] fragmentarycznie elementy jego myśli narzucają dostatecznie wyraziście potrzebę zaakcentowania w języku i jego opisach tego, co twórcze, indywidualne, fantastyczne, fantazyjne, wolne w dwójnasób; ani nie dające się zniewolić, ani niezdolne do zniewalania” (Pisarkowa 1994a: 42). „Atrakcyjność językoznawstwa jako partnera reprezentującego nowoczesność wynika z długotrwałego już związku partnerskiego ze strukturalizmem oraz ze świeżego romansu z cybernetyką i logiką formalną" (Pisarkowa 1999: 114). Łakomą partnerką dla wielu „niewinnych”, jeszcze nie zbuntowanych, usamodzielniających się nauk jest zwykła nauka dedukcyjna, nomotetyczna, formalna (formalistyczna), zdolna do inspiracji uogólnionych i uogól- 
niających. „Odkąd się do językoznawstwa wślizgnęła pragmatyka [...], odżyła [...] możliwość powrotu do tekstu [...]. Wraz z nią legalna stała się interpretacja tekstu" (Pisarkowa 1994a: 3). Przywołując ją w kontekście wyśmiewanych szkolnych pytań o to, „co autor chciał powiedzieć” swoim dziełem, Pisarkowa komentuje: „Odbywała się [...] ona cichcem, między wierszami, była słabością wstydliwą, nieracjonalną, pozbawionym narzędzi odruchem niekontrolowanej emocji. Dzięki temu była bezkarna" (ibid.: 4). Wiadomo, że wiele uwagi poświęcała tekstom poetyckim (pisząc także własne). Jednocześnie miała świadomość, że „Ulegamy złudzeniu [...], że każda liryka jest rozchwytywana, że każda jest gorąco zaangażowana w bezpośrednio ją dotykającą rzeczywistość polityczną, że każda żeruje na historii, literaturze i języku lub żywi się nimi. Tymczasem wcale tak nie jest" (ibid.: 9). Nawiązując do intencji aktów mowy, stwierdziła, że materia podświadomości jest śliska. Próby odkrywania i opisywania, a nawet klasyfikowania intencji aktu mowy ograniczają się zazwyczaj do grzebania w świadomości odbiorcy.

Wydaje się, że nie każdemu autorowi redaktorzy pozwoliliby na taki indywidualizm. Ale żeby mieć takie teksty, trzeba było być Pisarkową. „Miała w środowisku status gwiazdy” (Kałkowska 2010a: 414), zapewne między innymi dlatego, że „nie tylko miała imponująco rozległą wiedzę językoznawczą i dogłębne poczucie etyki naukowca i humanisty, ale także wykazywała subtelną wrażliwość na najdrobniejsze niuanse języka, na jego sensy i brzmienia" (Tabakowska 2010: 249).

Do walorów, jakie wymienił prof. Urbańczyk, pisząc K. Pisarkowej jubileuszową laurkę - że poza wybitną inteligencją, wiedzą i pomysłowością naukową ma Ona jeszcze „inne zalety, wesołe usposobienie, dowcip, [...] wdzięk osobisty” (Urbańczyk 1994: 8) - dodać by można i odwagę bycia sobą, która umożliwiła Jej wprowadzenie na parnas nauki licznych zjawisk z obrzeży językowych i wykreowanie ich na problemy nowoczesnej lingwistyki.

\section{Literatura}

BRISTIGER M., 1986, Związki muzyki ze słowem. Z zagadnień analizy muzycznej, „Biblioteka Res Facta", t. 4, Kraków.

HeInz A., 1978, Dzieje językoznawstwa w zarysie, Warszawa.

ImHasly B., 1974, Der Begriff der sprachlichen Kreativität in der neueren Linguistik, „Linguistische Arbeiten", t. 20, Tübingen, https://doi.org/10.1515/9783111357744.

Kaєkowska A., 2010a, Wspominając Profesor Krystynę Pisarkowa (30.01.1932 - 27.02.2010), „Stylistyka” XIX, s. 411-418.

Kaєkowska A., 2010b, Żegnając Profesor Krystynę Pisarkową (1932-2010), „Linguistica Copernicana" 4, nr 2, s. 15-23, https://doi.org/10.12775/LinCop.2010.016.

Kowalik K., 2010, Profesor Krystyna Pisarkowa (30 I 1932 - 27 II 2010), „LingVaria” nr 2 (10), s. 7-14 (tu dalsza literatura).

Kowalikówna K., 1974, Na marginesie badań nad frekwencja wyrazów we współczesnej polszczyźnie, [rec.] W. Pisarek, Frekwencja wyrazów w prasie: wiadomości, komentarze, 
reportaże, „Biblioteka Wiedzy o Prasie” seria B, t. 16, Kraków 1972, „Język Polski” LIV, s. $53-60$.

LAsкowsкi R., 1987, Niektóre trudności i kwestie sporne w opisie fleksji języka polskiego, „Studia Gramatyczne” VIII, s. 99-122.

Pisarek W., 2010, Krystyna Pisarkowa. Dzieło Jej życia (1932-2010), „Biuletyn Polskiego Towarzystwa Językoznawczego" LXVI, s. 5-22.

PIsarkowa K., 1963/1994, Pomocnicze elementy języka muzykologii, „Język Polski” XLIII, s. 113-128; przedruk w: eadem, Z pragmatycznej stylistyki, semantyki $i$ historii języka. Wybór zagadnień, „Prace Instytutu Języka Polskiego”, nr 89, Kraków 1994, s. 175-189.

Pisarkowa K., 1967a, Tango po niemiecku. Na marginesie niektórych przekładów Mrożka na język niemiecki, „Język Polski” XLVII, s. 373-379.

PIsARKowa K., 1967b, Zaimek w polskim zdaniu. 1. Obserwacje podmiotu zaimkowego w mowie potocznej, „Język Polski” XLVII, s. 21-37.

Pisarkowa K., 1969a, Główne zasługi profesora Klemensiewicza dla kultury języka, „Język Polski” XLIX, s. 249-262.

PISARKowa K., 1969b, Kaspar, czyli tresura poprzez język, „Dialog” 14, nr 6, s. 141-144.

Pisarkowa K., 1969c, Ze wspomnień o profesorze Zenonie Klemensiewiczu, „Język Polski” XLIX, s. 266-272.

PISARKowa K., 1971, Roman Ingarden a językoznawstwo (1893-1970), „Biuletyn Polskiego Towarzystwa Językoznawczego" XXIX, s. 3-11.

PISARKowa K., 1972, Szkic pola semantycznego zapachów w polszczyźnie, „Język Polski” LII, S. 330-339.

Pisarkowa K., 1973, Miejsce składni historycznej we współczesnym językoznawstwie polskim, „Język Polski” LIII, s. 158-172.

Pisarkowa K., 1976a, Konotacja semantyczna nazw narodowości w języku polskim, „Zeszyty Prasoznawcze" nr 1, s. 5-26.

Pisarkowa K., 1976b, Pragmatyczne spojrzenie na akt mowy, „Polonica” II, s. 265-279.

Pisarkowa K., 1977a, Odchylenie a kreatywność w języku potocznym, „Polonica” III, S. 141-179.

Pisarkowa K., 1977b, O dosłowności w języku literackim, „Zeszyty Naukowe Uniwersytetu Jagiellońskiego. Prace Językoznawcze" nr 54, s. 63-78.

PISARKowa K., 1977c, Rozważania o argumentacji w języku naturalnym, „Polonica” III, S. 79-88.

PISARKOWA K., 1978a, Jerzy Kuryłowicz, „Przekrój” nr 1717, s. 9.

PIsArkowa K., 1978b, Odchylenie twórcze w języku potocznym, [w:] M.R. Mayenowa (red.), Tekst, język, poetyka. Zbiór studiów, Wrocław, s. 163-172.

Pisarkowa K., 1978c, Pojęcie kreatywności językowej w nowej lingwistyce, „Biuletyn Polskiego Towarzystwa Językoznawczego" XXXVI, s. 13-31.

PIsARKowa K., 1981, Możliwości i ograniczenia opisu zmian składniowych w polszczyźnie, „Polonica” VI, s. 236-242.

Pisarkowa K., 1984, Historia składni języka polskiego, „Prace Instytutu Języka Polskiego”, nr 52, Wrocław.

Pisarkowa K., 1986a, Adam Heinz jako historyk językoznawstwa, „Biuletyn Polskiego Towarzystwa Językoznawczego" XL, s. 13-17.

Pisarkowa K., 1986b, W kręgu filozofii języka i wolności, „Język Polski” LXVI, s. 175-185. 
PIsArKowa K., 1988, Muzyka jako język, „Zeszyty Naukowe Uniwersytetu Jagiellońskiego. Prace Językoznawcze" nr 97, s. 13-40.

Pisarkowa K., 1992, Język okrąły jak pomarańcza, „Tygodnik Powszechny” nr 12, s. 7.

Pisarkowa K., 1994a, Język według Junga. O czytaniu intencji, „Nauka dla Wszystkich”, nr 466, Kraków.

PISARKowA K., 1994b, Z pragmatycznej stylistyki, semantyki i historii języka. Wybór zagadnień, „Prace Instytutu Języka Polskiego”, nr 89, Kraków.

Pisarkowa K., 1995a, Język według Bronisława Malinowskiego, „Sprawozdania z Czynności i Posiedzeń Polskiej Akademii Umiejętności” LIX, s. 16-20.

Pisarkowa K., 1995b, O stylu, „Stylistyka” IV, s. 283-287.

Pisarkowa K., 1996, Na marginesie wolności. Z pytań Malinowskiego do językoznawstwa, [w:] J. Mikułowski-Pomorski, Z. Bajka (red.), Valeriana. Eseje o komunikowaniu między ludźmi. Prace ofiarowane Profesorowi Waleremu Pisarkowi, Kraków, s. 226-236.

PIsAr Kowa K., 1998, Pragmatyka przekładu: przypadki poetyckie, „Prace Instytutu Języka Polskiego", nr 106, Kraków.

PISARKowA K., 1999, Stereotypy klasyfikacji nauk a jezzykoznawstwo, [w:] M. Wojtyła-Świerzowska (red.), Synchronia - diachronia. Materiały z konferencji „Problematyka historycznojęzykowa we współczesnym językoznawstwie i jej miejsce $w$ dydaktyce", WSP im. Jana Kochanowskiego, Kielce 17-18 XI 1997, Kielce, s. 109-119.

PIsArkowa K., 2000a, Historia języka a historia sztuki. „Psałterz” - studium przypadku, [w:] K. Rymut, W.R. Rzepka (red.), Rozwój polskiego systemu językowego, „Prace Instytutu Języka Polskiego”, nr 111, „Studia Historycznojęzykowe, nr 3, Kraków, s. 45-57.

Pisarkowa K., 200ob, Językoznawstwo Bronisława Malinowskiego, t. 1: Więzy wspólnego ję$z y k a$, Kraków.

Pisarkowa K. (red.), 200oc, Językoznawstwo Bronisława Malinowskiego, t. 2, Kraków.

Pisarkowa K., 2001, Mowa a postaci dewerbalizacji, [w:] I. Piechnik, M. Świątkowska (red.), Ślady obecności. Księga pamiątkowa ofiarowana Urszuli Dąmbskiej-Prokop przez kolegów, uczniów i przyjaciót, Kraków, s. 281-285.

Pisarkowa K., 2002, Tożsamość jednostki w świetle języka kultury, [w:] M. Krauz, K. Ożóg (red.), Składnia, stylistyka, struktura tekstu. Ksiega jubileuszowa dedykowana Profesor Teresie Ampel, Rzeszów, s. 27-32.

Pisarkowa K., 2006, Profesor Tadeusz Milewski (17 V 1906 - 5 III 1966), „Język Polski” LXXXVI, s. 321-322.

Pisarkowa K., 2007, Przyczynek do wyobrażeń o relacji między myśleniem a językiem, „Przegląd Humanistyczny” 1, s. 165-171.

Popper K., 1996, Świat skłonności, „Akademia - Znak”, Kraków.

Тавакоwska E., 2010, Wspomnienie o Pani Profesor Krystynie Pisarkowej, „Przekładaniec. A Journal of Translation Studies” nr 21: Historie przekładów, s. 249-250.

UrbaŃCZYK S. (red.), 1978, Encyklopedia wiedzy o języku polskim, Wrocław.

UrbaŃCZyк S. (red.), 1991, Encyklopedia języka polskiego, wyd. 2 popr. i uzup., Wrocław.

UrbańCZy K S., 1994, Profesor Krystyna Pisarkowa w roli Jubilata, [w:] K. Pisarkowa, Z pragmatycznej stylistyki, semantyki i historii języka. Wybór zagadnień, „Prace Instytutu Języka Polskiego", nr 89, Kraków, s. 5-8.

ZKSN1780-1822: Zapomniane konstrukcje składni nowopolskiej (1780-1822). Wybór przykładów, oprac. A. Kałkowska i in., Wrocław 1974. 
ZKSN1822-1863: Zapomniane konstrukcje składni nowopolskiej (1822-1863). Wybór przykładów, oprac. A. Kałkowska i in., Wrocław 1975.

ZKSN1863-1918: Zapomniane konstrukcje składni nowopolskiej (1863-1918). Wybór przykładów, oprac. A. Kałkowska i in., Wrocław 1977.

ZKSS: Zapomniane konstrukcje składni staropolskiej. Wybór przykładów, oprac. Z. Klemensiewicz, K. Pisarkowa, J. Konieczna-Twardzikowa, Wrocław 1966.

ZKSŚXVI: Zapomniane konstrukcje składni średniopolskiej (XVI wiek). Wybór przykładów, oprac. Z. Klemensiewicz i in., Wrocław 1971.

ZKSŚXVII: Zapomniane konstrukcje składni średniopolskiej (XVII wiek). Wybór przykładów, oprac. A. Kałkowska, K. Pisarkowa, J. Twardzikowa, Wrocław 1972.

ZKSŚ170o-1780: Zapomniane konstrukcje składni średniopolskiej (170o-1780). Wybór przykładów, oprac. A. Kałkowska i in., Wrocław 1973.

Bibliografię prac Krystyny Pisarkowej zamieszczają dwa wydawnictwa jubileuszowe: K. Pisarkowa, Z pragmatycznej stylistyki, semantyki i historii języka. Wybór zagadnień, „Prace Instytutu Języka Polskiego”, nr 89, Kraków 1994 (bibliografia z lat 1954-1992, s. 287-299); I. Bobrowski (red.), Anabasis. Prace ofiarowane Profesor Krystynie Pisarkowej, Kraków 2003 (bibliografia z lat 1992-2002, s. 7-14).

\section{Language and Linguistics According to Krystyna Pisarkowa (1932-2010) Abstract}

Krystyna Pisarkowa's rich output is characterised by a variety of forms and a wide range of topics, as well as an innovative interpretation of linguistic phenomena. The following paper can be described as biographical and substantive. The text contains certain facts from Pisarkowa's life that are connected with certain spheres of her scientific activity in which she succeeded, references to people who played a significant role in her life, as well as development of her research interests. The publications which are mentioned in the paper have been selected according to Pisarkowa's attitude to language, its essence, pragmatic-functional-stylistic variety, as well as potential context and purpose which lies beyond its typical usage. Moreover, an attempt has been made at reconstructing Pisarkowa's views on the range, shape and place of linguistics among humanistic disciplines. 